\title{
Cambrian Stratigraphy of San José de Gracia, Sonora, Mexico: El Gavilán Formation, a new lithostratigraphic unit of middle Cambrian open shelf environment
}

\author{
Francisco Javier Guen-Romero, José Eduardo Valdez-Holguín, Blanca Estela Buitrón, \\ Rogelio Monreal, Frederick Sundberg, Alejandra Montijo-González, \\ Ismael Minjarez-Sosa
}

\begin{abstract}
Francisco Javier Guen-Romero
Departamento de Geología, Universidad de Sonora, Blvd. Luis Encinas y Rosales, CP 83000, Hermosillo, Sonora, México.

\author{
José Eduardo Valdez-Holguín \\ jvaldez@guayacan.uson.mx \\ Departamento de Investigaciones Científicas y \\ Tecnológicas, Universidad de Sonora, Luis Donaldo \\ Colosio s/n, entre Sahuaripa y Reforma, Col \\ Centro. CP. 83000, Hermosillo, Sonora, México.
}

Blanca Estela Buitrón

Departamento de Paleontología, Instituto de

Geología, Universidad Nacional Autónoma de México, Ciudad Universitaria, CP 04510, CDMX., México.

\section{Rogelio Monreal}

Departamento de Geología, Universidad de Sonora, Blvd. Luis Encinas y Rosales, CP 83000, Hermosillo, Sonora, México.

\section{Frederick Sundberg}

Show Low High School, 500 W. Old Linden Road, Show Low, AZ, USA.

\section{Alejandra Montijo-González}

Departamento de Geología, Universidad de Sonora, Blvd. Luis Encinas y Rosales, CP 83000, Hermosillo, Sonora, México.

\section{Ismael Minjarez-Sosa}

Departamento de Geología, Universidad de Sonora, Blvd. Luis Encinas y Rosales, CP 83000, Hermosillo, Sonora, México.

BOL. SOC. GEOL. MEX. 2016

VOL. 68 NO. 3

P. $429-441$

Manuscript received: January 4, 2016 Corrected manuscript: February 2, 2016 Manuscript accepted: February 6, 2016

\begin{abstract}
An approximately $600 \mathrm{~m}$ interval of Cambrian strata is exposed near the town of San José de Gracia, Sonora, Mexico. This succession is divided into four formations, one of which is proposed here as a new formal stratigraphic unit: El Gavilán Formation, following the rules of the North American Commission on Stratigraphic Nomenclature. The new nomenclature reflects substantial lithologic differences, particularly in the middle Cambrian strata in comparison with other Cambrian rocks exposed in other parts of the state. The Proveedora Formation consists of bioturbated, fine-grained quartz arenite with ichnofossils; the Buelna Formation consists of interbedded limestone and sandstone, with abundant trilobites of either the ?Bristolia mohavensis or ?Bristolia insolens Zone (Series 2?, Stage 4?); the Cerro Prieto Formation is a highly recrystallized oolitic limestone with fragments of ?Amecephalus arrojosensis at the base, suggesting the $A$. arrojosensis Biozone (Series 2?; Stage 4?); and the El Gavilán Formation consists of interbedded limestone and intensely fractured red shale, with abundant fauna of the upper part of the Mexicella mexicana Zone, Albertella highlandensis Subzone, Ptychagnostus praecurrens Zone (open shelf) (Series 3?, Stage 5?).

The Cambrian rocks of Sonora were deposited in the occidental part of the North American craton during the early and middle Cambrian, when Laurentia must have been constituted by terrestrial masses near the paleoequator, aligned in an east-west direction, providing the right conditions for an abundant invertebrate marine fauna.
\end{abstract}

Keywords: Cambrian, Stratigraphy, Sonora, Mexico.

\section{RESUMEN}

Una sucesión estratigráfica del Cámbrico de aproximadamente $600 \mathrm{~m}$ de espesor aflora en San Fosé de Gracia, Sonora, México. Esta sucesión está dividida en cuatro formaciones, una de las cuales se propone aquí como una nueva unidad estratigráfica formal: la Formación El Gavilán, siguiendo las reglas de North American Commission on Stratigraphic Nomenclature. La nueva nomenclatura refleja diferencias litológicas substanciales, particularmente en los estratos del Cámbrico medio en comparación con otras rocas cámbricas expuestas en otras ubicaciones del estado. Las formaciones Proveedora, Buelna, Cerro Prieto y El Gavilán constituyen una sucesión detrítico-carbonatada, la cual se expande sobre una porción considerable del Cámbrico inferior y medio en la Loma El Chihuarruita. Un amplio rango de ambientes de depósito se encuentra representado por la sucesión cámbrica en esta región, mostrando algunos cambios en comparación con las formaciones cámbricas del área de Caborca.

La Formación Proveedora está compuesta por cuarzoarenita de grano fino con bioturbación e icnofósiles; la Formación Buelna consiste de una intercalación de caliza y arenisca, con abundante fauna del Cámbrico Serie 2?, Piso 4?, asignada a la Zona de ?Bristolia mohavensis o ?'Bristolia insolens; la Formación Cerro Prieto es una caliza oolítica fuertemente recristalizada y con fragmentos de? Amecephalus arrojosensis en su base, sugiriendo la Zona de Amecephalus arrojosensis (Serie 2?; Piso 4?); y la Formación El Gavilán consiste en una intercalación de caliza y lutita de color rojo intensamente fracturada, con abundante fauna del Cámbrico Serie 3?, Piso 5?, asignada a la parte superior de la Zona de Mexicella mexicana, Subzona de Albertella highlandensis, Zona de Ptychagnostus praecurrens (plataforma abierta).

Las rocas cámbricas de Sonora fueron depositadas en la parte occidental del cratón norteamericano, durante el Cámbrico temprano y medio. En estas épocas, Laurentia debió constituir masas terrestres cercanas al ecuador, alineadas en dirección este-oeste, proporcionando las condiciones que favorecieron una abundante fauna de invertebrados marinos.

Palabras clave: Cámbrico, Estratigrafía, Sonora, México. 


\section{Introduction}

Lower Paleozoic sedimentary rocks are poorly represented in Mexico, with the majority located in the states of Sonora, Chihuahua, Tamaulipas and Oaxaca (Buitrón, 1992; Cuen, 2012). The Cambrian System in Sonora occurs in isolated and sporadic outcrops. Consequently, this system is poorly known from a stratigraphic viewpoint, though its fauna is well preserved.

A complete, though structurally thinned section of El Chihuarruita Hill, located $2 \mathrm{~km}$ southeast of the town of San José de Gracia, is described here. The Cambrian section exposed in the San José de Gracia region is similar to the section originally established in the northwest part of the Caborca area by Cooper et al. (1952), including the Proveedora, Buelna, and Cerro Prieto formations. The El Gavilán Formation occurring above the Cerro Prieto Formation is proposed herein.

\subsection{PREVIOUS WORKS}

The presence of Cambrian rocks in the state of Sonora has been known since the middle of the last century (Cooper and Arellano, 1946; Lochman, 1948; Álvarez, 1949; Cooper et al., 1952; 1956). These rocks have been the subject of many stratigraphic, paleontological and, to a lesser extent, sedimentological studies.

The studies carried out in the Caborca area (Lochman, 1948; Cooper et al., 1952; 1956) were the first significant papers published on the Cambrian of Mexico. Near the town of Caborca, Cambrian strata crop out over much of the Proveedora and Buelna hills. These rocks were divided by Cooper et al. (1952) into six formations: Puerto Blanco, Proveedora, Buelna, Cerro Prieto, Arrojos and El Tren. Although a complete, continuous Cambrian section is not preserved at any location, there is a composite section of strata that has an aggregate thickness of approximately one kilometer in this region.

Cirett and Aguilar (1989), who discovered the Cambrian rocks of the San José de Gracia area, studied the stratigraphy of the rocks in the region, identifying the strata as the Proveedora, Buelna and Cerro Prieto formations, and included them as part of the San José group. The first official work in that area was published by Maytorena-Silva et al. (1990), who reported the presence of Cambrian rocks and their tectonic implications in the central part of the state of Sonora.

The Cambrian section is overlain and surrounded by the Neogene conglomerates and volcanic deposits studied by Bartolini et al. (2001) who made a stratigraphic and geochronological study (K-Ar) of the tertiary rocks in San José de Gracia. They defined tertiary conglomerates and volcanic rocks as a set of plateaus oriented in a north-south direction, with inclined blocks; those volcanoclastic sequences overlie unconformably the Paleozoic sequences.

Almazán-Vázquez (2002) carried out the first paleontological study of the Cambrian rocks in San José de Gracia. This researcher divided the sedimentary sequence of El Chihuarruita Hill into seven members (A-G). Stewart et al. (2002) collected fossils of Oryctocara sp., Peronopsis sp. cf. P. bonnerensis?, P. brighamensis, Oryctocephalus sp., Pagetia sp. and ?Ehmaniella sp. identified by Allison Palmer. Later, Buitrón et al. (2004) reported the presence of Gogia spiralis and the presence of the trilobites Bristolia sp. cf. B. bristolensis in the lower Cambrian and Peronopsis sp. cf. P. bonnerensis in the middle Cambrian. Cuen et al. (2009) assigned the rocks of the lower Cambrian to the Olenellus Zone and correlated them with the rocks located in southern USA. Nardin et al. (2009), in a reevaluation of the fossil material reported by Buitron (op cit.), carried out a palaeoecological and systematic study of Gogia granulosa Robison, 1965, and a detailed description of the members proposed by other researchers. Buitrón et al. (2011) reported the presence of the mollusks Hyolithes sonora Lochman in Cooper et al., 1952 and Haplophrentis reesei Babcock and Robison, 1988. Later, Huerta-Ruiz (2011), in an undergraduate thesis, carried out a detailed study of those species, although it has not been published yet. Guen (2012) carried out a detailed study of the 
stratigraphy and paleontology of the Cambrian rocks in this area and established them as reference sections for the Caborca area, identifying the Proveedora, Buelna, Cerro Prieto and Arrojos formations with a change of facies toward outer environments. The same researcher made a reevaluation of the fossil fauna, identifying the presence of Ogygopsis typicalis, Pagetia sp., Lingulella sp. and sclerites of Chancelloria sp., with the possible presence of Salterella sp. Cuen et al. (2012) reported the presence of the Albertella Zone in the Arrojos Formation because of the presence of Oryctocephalus sp., Oryctocephalites walcotti, Ogygopsis typicalis, El- rathina antiqua, Bathyuriscus sp., Peronopsis bonnerensis and Pagetia reeseri (identified by F. A. Sundberg) and sclerites of Chancelloria sp. cf. C. eros Walcott, 1920.

\section{Location}

The study area is located in the El Chihuarruita Hill, $29^{\circ} 17^{\prime} \mathrm{N}$ latitude and $110^{\circ} 35^{\prime} \mathrm{W}$ longitude, southeast of the town of San Jose de Gracia; about $36 \mathrm{~km}$ northwest of Hermosillo, the largest city near the study area (Figure 1).

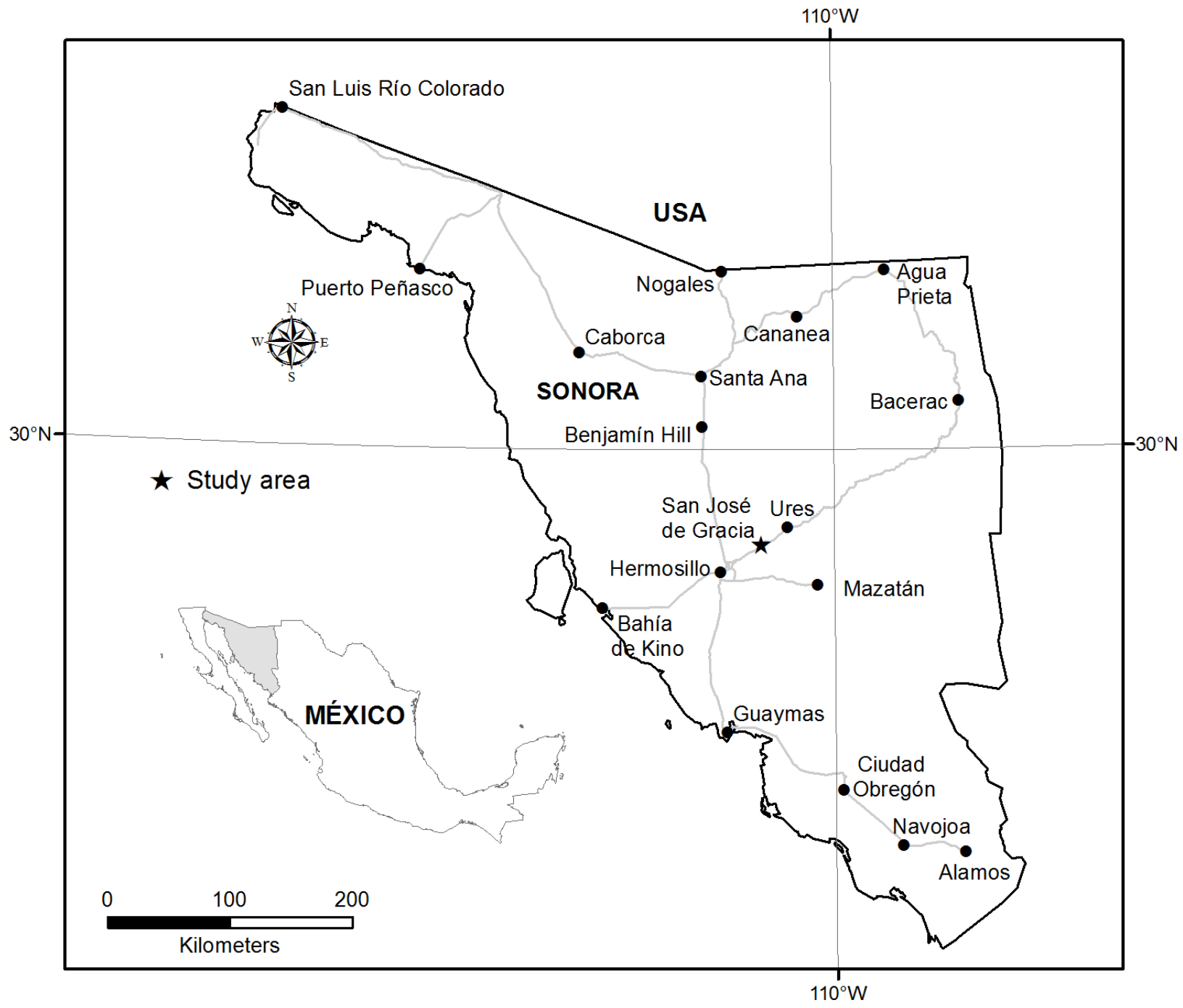




\section{Lithostratigraphy}

The stratigraphic units in the San José de Gracia area range from lower to middle Cambrian. The units present in the El Chihuarruita Hill, in ascending order, are: Proveedora, Buelna, Cerro Prieto and El Gavilán formations (Figures 2 and 3). This Cambrian sequence has been previously discussed by Maytorena-Silva et al. (1990), Almazán-Vázquez (2002), Nardin et al. (2009), Guen (2012), Guen et al. (2012), and Guen et al. (2013).

\subsection{PROVEEDORA FORMATION}

Definition and nomenclature background: The Proveedora Formation was defined in the Proveedora Hills in the Caborca area of Sonora (Cooper et al., 1952). It is composed of interbedded quartzite and sandstone. The unit has a thickness of 226 $\mathrm{m}$. Quartzite at the base is white, with shades of gray and iron oxide stains. The fine-grained sandstones are brown and dark green. At the top there is a $37 \mathrm{~m}$ horizon of quartzarenite, occasionally metamorphosed, with indeterminate fragments of trilobites (Cooper et al., 1952). In the San José de Gracia area, the Proveedora Formation is composed of a pink quartzarenite, with oxide stains exposed at the top of El Chihuarruita Hill.

Nardin et al. (2009) published the first detailed work on the stratigraphy of the Cambrian rocks in San José de Gracia, dividing them into three informal members (A, B, C), composed of alternating quartzites and sandstones. Cuen (2012) assigned these rocks to the Proveedora Formation, given their similarity to the type of sections from the Caborca area.

Lithology and thickness: This unit is approximately $225 \mathrm{~m}$ thick. At its base there is a dark brown quartzite package, with a quartz grains less than $1 \mathrm{~mm}$ in size, subrounded and generally well sorted. Strata less than $1 \mathrm{~m}$ thick have abundant oxide stains. This lower portion has a laminar and cross-bedded stratification. The next layer consists of a coarse-grained sandstone, dark and yellow in color, commonly conglomeratic, with clasts of sub-angular to subrounded gravel. Above it, there is a package of fine-grained quartzarenite, of a cherry and dark brown color, followed by a pink sandstone with oxide stains. It has a laminar and cross-bedded stratification. The uppermost package is a massive sandstone. The clasts are of the same size and roundness as those of the package below. This package shows variations from fine-grained to coarse-grained sandstones, with oxidized pyrite crystals of $1 \mathrm{~mm}$ in size. These sandstones are composed of more than $90 \%$ quartz grains, varying in size from 0.40 to 0.15 $\mathrm{mm}$, and showing quartz overgrowths. In thin sections, grain contacts vary from concave-convex to straight, and a few sutured grains can be observed. Feldspar grains are rare to absent, but there is altered plagioclase as well as alteration to green and yellow clays. The rare rock fragments also observed are flint.

Distribution: The Proveedora Formation in the study area outcrops only at the top of El Chihuarruita Hill.

Boundary relationships: The lower contact is covered by volcanic rocks of tertiary age. The Proveedora Formation is conformably overlain by the lower Cambrian Buelna Formation.

Section and type area: The type section of Proveedora Formation is located in the Proveedora Hills, in the Caborca area. The reference section in San José de Gracia is located at the geographic coordinates $29^{\circ} 17^{\prime} 05^{\prime \prime} \mathrm{N}$ and $110^{\circ} 34^{\prime} 60^{\prime \prime} \mathrm{W}$, where a NW-SE oriented section of $225 \mathrm{~m}$ was measured. Fossils and chronostratigraphic position: The Proveedora Formation does not have body fossils, however, in the coarse-grained sandstone of the upper part are the ichnofossils Skolithos isp. cf. $S$. linearis Haldeman, 1840; Palaeophycus isp., Planolites isp., Diplocraterion isp. and Arenicolites isp. Although the Proveedora Formation and the overlying formation does not have index fossils, based on its correlation with the Caborca area, it is assigned to the lower Cambrian.

Depositional environment: Considering that Proveedora is a cross-bedded quarzarenite and that 


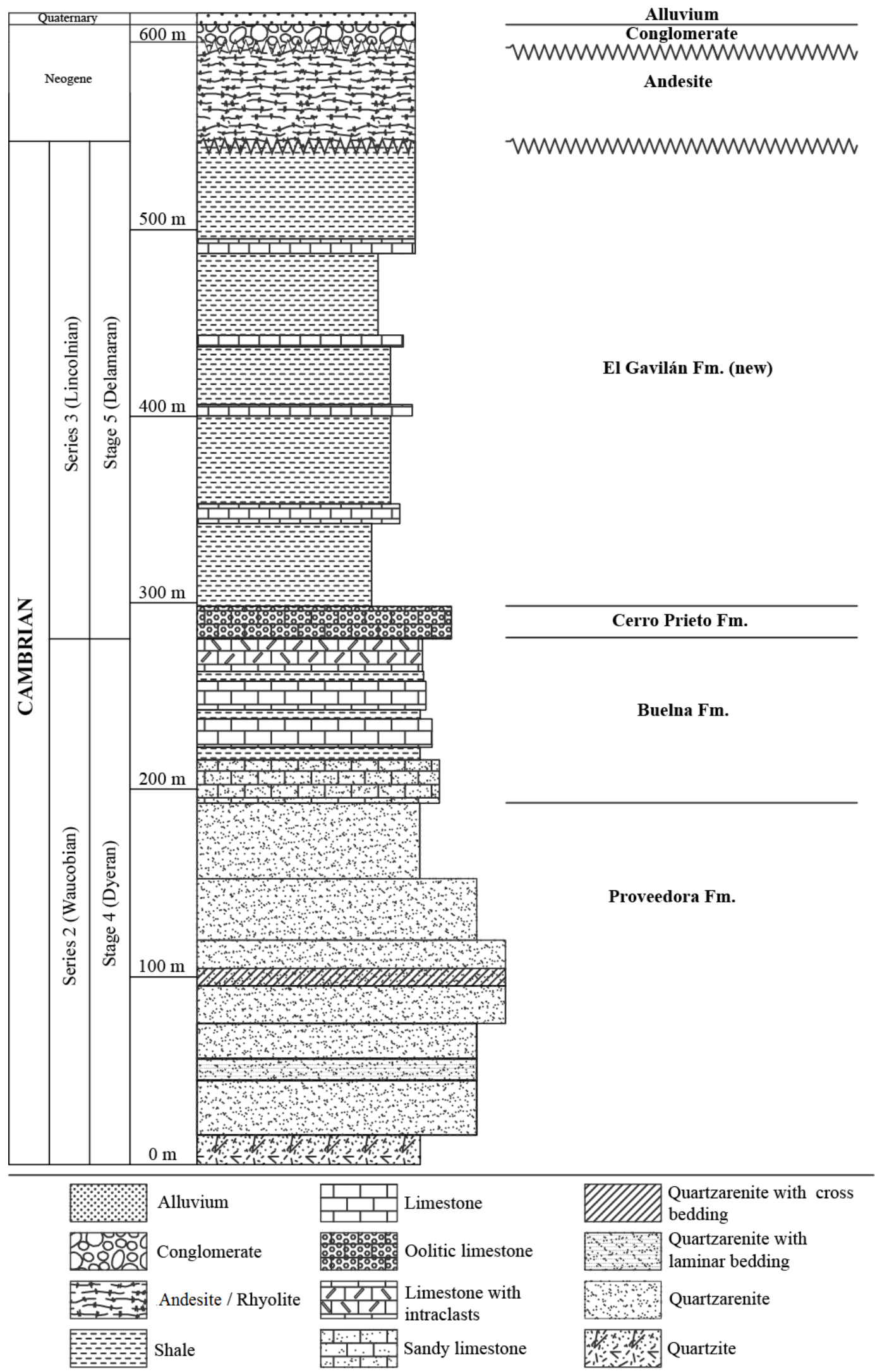




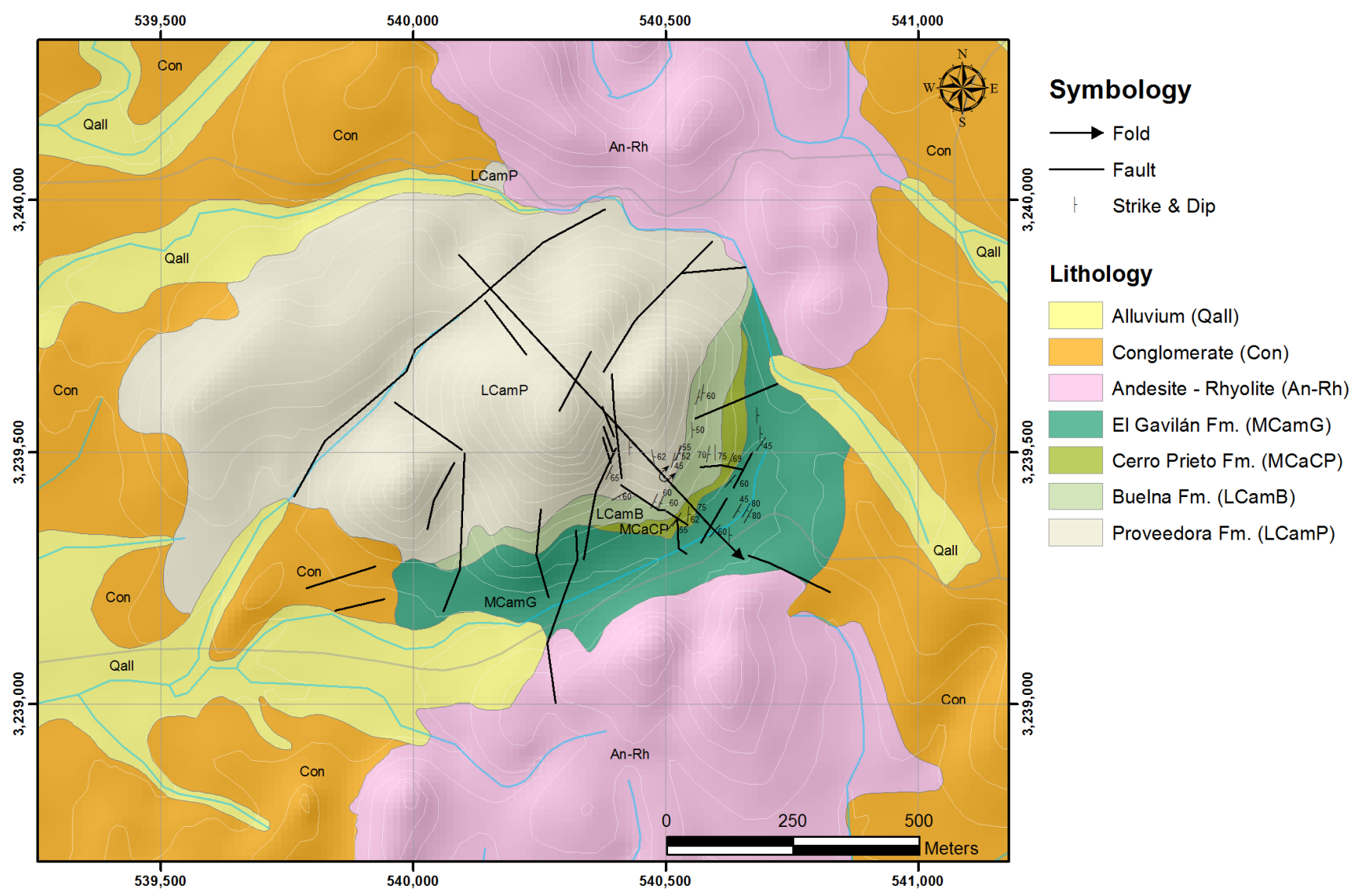

Figure 3 Geologic map. The principal topographic feature in the area is El Chihuarruita Hill, located in the center of the image and containing the main Cambrian stratigraphic units. The El Chihuarruita Hill has an elevation of approximately 450 masl and it is surrounded by different secondary rivers which flow west, crossing the town of San José de Gracia and finally connecting with the Sonora River. The scale of the coordinate system is in meters.

it contains Skolithos isp. cf. S. linearis, Arenicolites isp. and Planolites isp., which are representative of the Skolithos ichnofacies (Seilacher, 1964), the Proveedora Formation in the San José de Gracia area was deposited in an intertidal or shallow subtidal environment. This is consistent with the interpretation of Rivera-Carranco (1988) that the Proveedora Formation in the Caborca area was deposited in a shallow environment, infratidal or intertidal.

Regional correlation: The Proveedora Formation in the Caborca area, as well as in the San José de Gracia area, has a similar base (quartzite and sandstone), thickness, and stratigraphic position. In the Caborca area it conformably overlies the Puerto Blanco Formation and it is conformably overlain by the Buelna Formation. In the San José de Gracia area, the lower contact of the Proveedora Formation is covered. The Proveedora Formation in the Caborca area varies from 225 to $260 \mathrm{~m}$ (Cooper et al., 1952), and it is only $45 \mathrm{~m}$ thick in the Cerro Prieto area. In the San José de Gracia area it has a thickness of $225 \mathrm{~m}$. The Proveedora Formation in the Caborca area contains poorly preserved fragments of olenellids and lingullids, with abundant Skolithos (Cooper et al., 1952). In the San José de Gracia area, only ichnofossils have been observed, mainly Skolithos isp. cf. S.linearis.

\subsection{BUELNA FORMATION}

Definition and nomenclature background: The Buelna Formation was defined Buelna Hill, in the Caborca area (Cooper et al., 1952). It consists 
mainly of grained limestone interbedded with sandstones. The sandstones are thin-bedded, fine-grained and have a dark brown color, sometimes fissile, with red shale in contact with the Cerro Prieto Formation. The limestone is gray, sandy, and sometimes green in color. At the base there is limestone with abundant Salterella sp. and trilobites, which appear to have been accumulated by high energy currents. In the middle part of this formation there are two resistant ridges made up of banks of oncolitic limestone. The upper part of the formation is composed of shale containing thin beds of calcareous sandstone and oolitic or intraformational limestones, with abundant trilobites. In the upper middle part, the trilobites Onchocephalus, Bonnia and "Antagmus" are found (Cooper et al., 1956; Rivera-Carranco, 1988). The thickness of the formation is $70 \mathrm{~m}$, and conformable with the underlying Proveedora and overlying Cerro Prieto formations.

Lithology and thickness: The Buelna Formation is an approximately $74 \mathrm{~m}$ thick interval composed of sandy limestone interbedded with shale. At its base, a $10 \mathrm{~m}$ thick dark gray limestone outcrops with abundant fragments of Bristolia sp. cf. B. bristolensis and Olenellus sp. Above is a $1 \mathrm{~m}$ thick, purple sandy limestone. This layer consists of quartz grains in an oxidized calcareous matrix. The grains of quartz range from 150 to $300 \mu \mathrm{m}$, and are generally angular to subangular and poorly classified in size. This bed has a thickness of $19 \mathrm{~m}$. Overlying $40 \mathrm{~m}$ of strata are interbedded shales and limestones. The limestones are packstone and biomicrite with greater than $50 \%$ allochems, consisting of hyolithids and trilobites fragments. A $6 \mathrm{~m}$ sequence of unfossiliferous shales is poorly exposed. A 9 $m$ thick yellow and brown bed of limestone comes next, with a high content of oncolites. The oncolites range in size from approximately 5 to $25 \mathrm{~mm}$ in diameter, with $0.2-1.00 \mathrm{~mm}$ thick concentric laminations; they are gray and black in color and are found in a matrix of packstone altered to hematite. This study shows that the filaments do not belong to Girvanella (Beraldi-Campesi et al., 2013). At the top, a bed of dark-gray limestone, with sandy, tabular, yellow, $10-15 \mathrm{~cm}$ long intraclasts. This unit is about $74 \mathrm{~m}$ thick.

Distribution: The Buelna Formation outcrops only in the southeast part of El Chihuarruita Hill.

Boundary relationships: The Buelna Formation conformably overlies the Proveedora Formation and is conformably overlain by the Cerro Prieto Formation.

Section and type area: The Buelna Formation derives its name from Buelna Hill, Caborca, type locality. In the San José de Gracia area, a reference section of $74 \mathrm{~m}$, with a direction NW-SE was measured.

Fossils and chronostratigraphic position: In the middle part of this unit there are abundant Hyolithes sonora Lochman in Cooper et al., 1952 and $\mathrm{Ha}^{-}$ plophrentis reesei Babcock and Robison, 1988, as well as Salterella sp. These are associated with abundant olenellids, identified as Olenellus sp. and Bristolia sp. cf. B. bristolensis. The faunal assemblage indicates a Cambrian age Series 2?, Stage 4?.

Depositional environment: The depositional environment is shallow, quiet marine waters, with an input of terrigenous matter, as shown by limestone with fragments of angular quartz grains, which suggest possible storms. A wave accumulation of fossils is also found, as most fragments are broken. The analysis of samples in thin sections shows packstones with input of detritus, indicating a subtidal setting below wave base, but above storm wave base (Wilson, 1975).

Regional correlation: The Buelna Formation in the Caborca area is correlated with that of the San José de Gracia area, based on several considerations. 1) Both units have a similar lithological composition. The Buelna Formation in Caborca has, at its base, a sandy gray limestone, interbedded with sandstone, with beds containing fragments of Olenellus. In the middle part of the unit a gray limestone with abundant Girvanella crops out, and in the upper part it is possible to find trilobites and Salterella sp. In San José de Gracia, the Buelna Formation has the same lithologic content, albeit more or less abundant. 2) The stratigraphic position of both units is the same. They overlie 
the Proveedora Formation and are overlain by the Cerro Prieto Formation. In addition, both contacts, lower and upper, are conformable. 3) The thickness of both units is very similar $(70 \mathrm{~m}$ and $74 \mathrm{~m}$, for the Buelna Formation in Caborca and in San José de Gracia, respectively).

The Buelna Formation in the San José de Gracia area can be correlated with the Thimble Limestone Member of the Carrara Formation(California), where fragments of Bristolia bristolensis and Olenellus are also abundant (Palmer and Halley, 1979).

\subsection{CERRO PRIETO FORMATION}

Definition and nomenclature background of the unit: The Cerro Prieto Formation was defined in the Cerro Prieto Hill, in Caborca (Cooper et al., 1952). It consists of black and massive limestone with some oncolitic and bioturbated horizons. This unit did not provide index fossils. It is considered controversial or maybe it can be placed in the transition from lower to middle Cambrian. The lower contact with the Buelna Formation is conformable and the upper contact with the Arrojos Formation is normal. This unit is $110 \mathrm{~m}$ in the Caborca area (Cooper et al., 1952).

Lithology and thickness: This unit is represented by a massive oolitic limestone of dark gray color, with a thickness of $17 \mathrm{~m}$. The unit is dolomitized and shows prominent cliffs, with strong karst weathering. In hand samples, oolites can be viewed as very rusty, orange in color and with a diameter of less than $1 \mathrm{~mm}$. In some parts, it is possible to see white calcite veins $1 \mathrm{~mm}$ thick. The presence of crystals of hematite and oxidized pyrite is common.

In thin sections, it is described as a mudstone matrix with recrystallized oolites, with a diameter of about $100 \mu \mathrm{m}$. The classification of Folk (1965) indicates an oomicrite.

Distribution: This unit can be located in the southeast of El Chihuarruita Hill only.

Boundary relationships: The Cerro Prieto Formation conformably overlies the Buelna Formation. The El Gavilán Formation is overlain by the Cerro Prieto Formation with a conformable contact.
Section and type area: The Cerro Prieto Formation has its type locality in the Cerro Prieto Hill, located $3 \mathrm{~km}$ southwest of Caborca. For the study, a $17 \mathrm{~m}$ section was measured.

Fossils and chronostratigraphic position: The unit provided some fragments of middle Cambrian trilobites Amecephalus arrojosensis.

Depositional environment: The deposit and formation of oolites occur in highly agitated and supersaturated shallow waters. For this reason, they are commonly found in zones with high tide activity, in a subtidal or intertidal environment. Given this, the high abundance of oolites in the Cerro Prieto Formation suggests that it was deposited in a shallow marine environment of high energy banks, although it contains a micrite matrix suggesting a lower energy environment of deposition. Regional correlation: Several considerations suggest that the Cerro Prieto Formation in the San José de Gracia area is correlated with that in the Caborca area. 1) In the Caborca area, the Cerro Prieto Formation outcrops as a dark gray limestone, commonly forming cliffs. In San José de Gracia, the unit outcrops in the same way. 2) The stratigraphic position of both units is similar: both conformably overlie the Buelna Formation and are overlain by the Arrojos Formation in Caborca and by the El Gavilán Formation in San José de Gracia. 3) The thickness of both units is different. In the Caborca area, the Cerro Prieto Formation has a thickness of $85-122 \mathrm{~m}$, while in Los Arrojos Hill it varies between 100 and $110 \mathrm{~m}$. In the San José de Gracia area a section of $17 \mathrm{~m}$ was measured.

\subsection{EL GAVILÁN FORMATION (NEW)}

Definition and nomenclatural background of the unit: El Gavilán Formation is defined as a succession of mainly red colored shales and interbedded gray limestones. This formation contains abundant fossils of the Cambrian Series 3?, Stage 5? (Traditional middle Cambrian) and outcrops in the upper part of the Cambrian sequence of San José de Gracia, Sonora that is lithologically different from the Arrojos Formation in Caborca. 
The studies carried out by other researchers in the area of El Chihuarruita Hill did not provide adequate terminology for the lithostratigraphic units of the Cambrian. The terminology proposed by Nardin et al. (2009), who divided the whole sequence into members from $\mathrm{A}$ to $\mathrm{G}$, is inadequate as it does not provide the necessary data for their utilization as a new nomenclature following the North American Stratigraphic Code (NASC, 2005) for the definition of formal units (Arts. 3-16). In addition, the establishment of new units or members, in the lower levels of the sequence, is not justifiable, because, based on their lithology and fossil fauna, these correspond to the Proveedora, Buelna and Cerro Prieto units proposed by Cooper et al. (1952) in the Caborca area.

The units in the San José de Gracia area are accepted as reference sections in the Caborca area. Therefore, we propose this new unit: El Gavilán Formation. This is entirely appropriate as this unit has a different lithology from the Arrojos Formation, or any other formal unit for that matter.

El Gavilán Formation is proposed here as a new lithostratigraphic unit with a status of formation (NACS, 2005). The name is derived from the El Gavilán River, located $4.5 \mathrm{~km}$ west of the El Chihuarruita Hill, where the type section of the El Gavilán Formation is located. El Gavilán Formation has its type area southeast of El Chihuarruita Hill (geographic coordinates $29^{\circ} 17^{\prime} 03^{\prime \prime} \mathrm{N}$ and $110^{\circ} 34^{\prime} 54^{\prime}$ W). It is located approximately $2 \mathrm{~km}$ southeast of the town of San José de Gracia, Sonora. It is notable because of the red color of the shale, which is generally highly fractured.

Lithology and thickness: El Gavilán Formation is composed of interbedded red shale and dark gray limestone. The predominant lithology is red shale with a thickness of less than $3 \mathrm{~cm}$. The limestone beds have a thickness of $30-50 \mathrm{~cm}$, and though these occur less frequently, they have good preservation of faunal content. El Gavilán Formation has a thickness of $233 \mathrm{~m}$.

This unit has abundant trilobites, inarticulate and articulate brachiopods, sponge spicules, chancellorids, and hyolithids, among others. In the basal part of the unit, the brachiopods Acrothele sp. and Linnarssonia sp. commonly occur in shale beds. Above this, in the upper shale beds, the fauna becomes very abundant, where the trilobites Peronopsis sp. cf. P. bonnerensis, Oryctocephalus sp., Oryctocephalites walcotti, Elrathina antiqua, Ogygopsis typicalis, Bathyuriscus sp. and Pagetia resseri can be identified. At the top of the unit, spicules of hexactinellids sponges were collected as well as isolated sclerites of Chancelloria eros and Diagoniella sp. (Guen et al., 2013).

Boundary relationships: The lower contact is conformable with the Cerro Prieto Formation. The upper contact is unconformable with Tertiary volcanic rocks.

Historical background: Nardin et al. (2009) included the rocks of this unit in members $F$ and $G$, reporting a large quantity of trilobites and brachiopods, assigning them to the Albertella and Glossopleura zones. Cuen (2012) assigned these rocks to part of the Arrojos Formation and included them in the Oryctocephalus Zone, proposing these rocks as a reference section for the Caborca area. However, this unit is proposed herein as a new lithostratigraphic formation, the El Gavilán Formation, replacing the informal formation names already established by other researchers.

Dimensions, form and regional aspect: The unit can be easily recognized in the field as it comprises a potent sequence of strongly fractured red shale interbedded with dark gray limestone beds.

Age: Based on the faunal content of the unit, it is assigned to a Cambrian Series 3?, Stage 5? (typical middle Cambrian). These rocks belong to the Mexicella mexicana Biozone, Albertella highlandensis Subzone and Ptychagnostus praecurrens Zone for open shelf environments.

Regional correlation: The El Gavilán Formation can be biostratigraphically correlated with the upper part of the Red Pass Limestone Member of the Carrara Formation (Palmer and Halley, 1979) in California, and with the Emigrant Formation located in Groom Range, Nevada (Sundberg and McCollum, 2003). Both localities have the Mexicella mexicana Zone and they were deposited in an open shelf environment. The El Gavilán Forma- 
tion can also be correlated with the Grassy Springs Member of the Pioche Formation, Oak Springs, Delamar Mountains (Sundberg, 2011). The lower part of the Arrojos Formation (Caborca) could be lithostratigraphically correlated with the lower part of El Gavilán Formation but with some chan- ges in the strata. (Figure 4).

Depositional environment: The studies carried out by Sundberg (2011) in the southeast of Nevada, in the Delamaran Stage deposits show lithological and paleontological changes in an west-east direction, starting from a deposit dominated by shallow

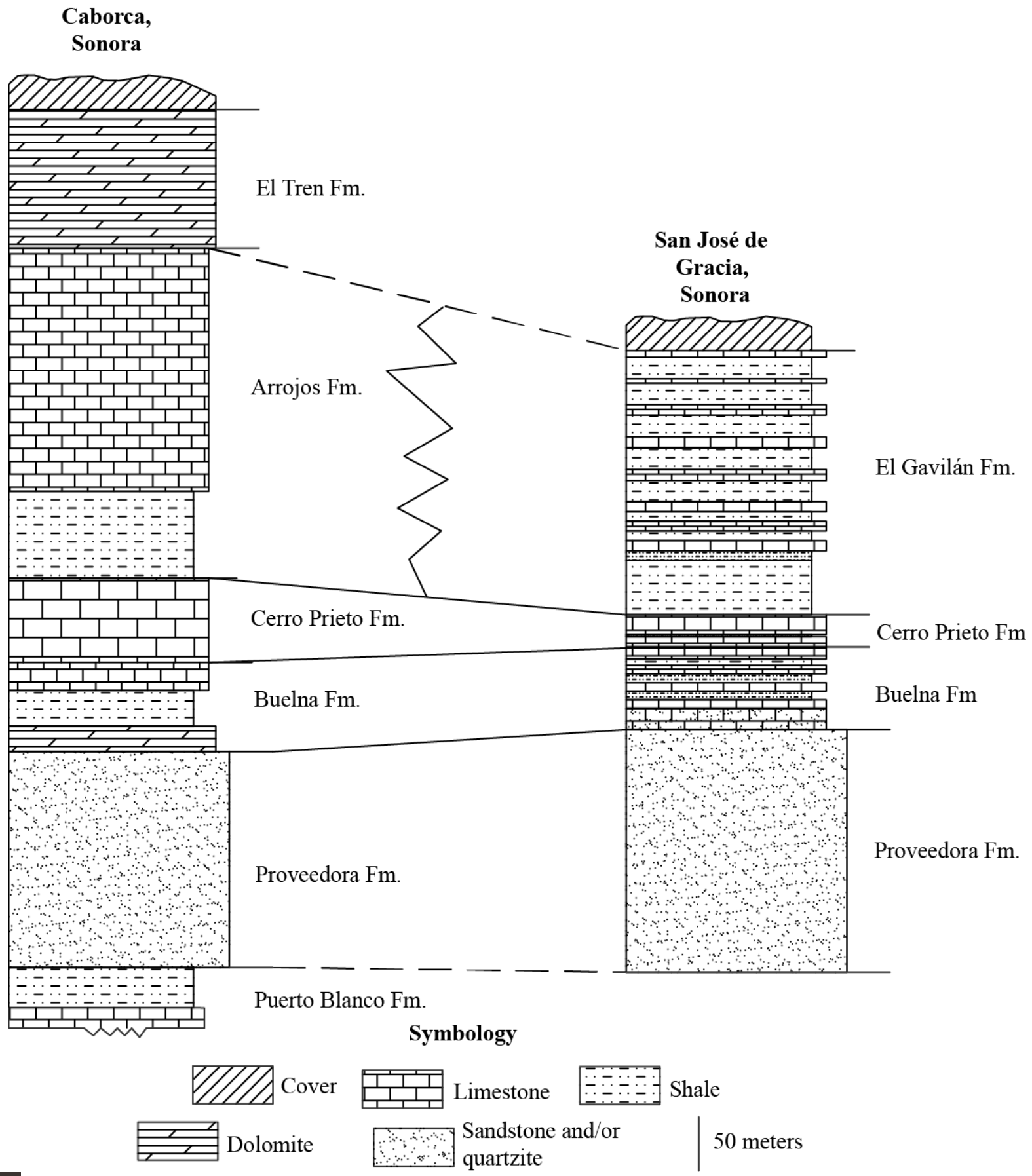

Figure 4 Lithostratigraphic correlation between the San José de Gracia and Caborca, Sonora, units (Modified from Stewart et al., 1984). 
waters, including bioturbation, oolites, sandstones, oncolites and mudstones. Also, this zone shows a large quantity of trilobites that can be divided into many biozones. The rocks of the outer shelf are dominated mainly by deep water containing shale, limestone with flint bands and laminar mudstone. Trilobites are less common in this region. The open shelf (intermediate) is located between the two zones mentioned above and is characterized by a lithologic mix of both facies (Sundberg, 2011).

\section{Conclusions}

The stratigraphic characteristics of the Cambrian formations in the areas of Caborca and San José de Gracia indicate a similarity in the lithology and faunal content, with the exception of the El Gavilán Formation.

In this paper, the presence of ?Amecephalus arrojosensis at the base of the Cerro Prieto Formation is reported for the first time. The El Gavilán Formation is composed of a set of detrital and carbonated materials, mainly shale and limestone, with abundant fossils of the traditional middle Cambrian period.

The Delamaran strata in south-central Nevada represent an environment of deeper water than the open shelf. Those strata include shale, black shale and laminar limestone, with abundant oncolitic limestone in the upper and lower parts of the sequence. In this environment, Sundberg (op cit.) reported the presence of the trilobites Peronopsis bonnerensis, Ogygopsis typicalis, Pagetia resseri, Elrathina antiqua, Pagetia rugosa, and Oryctocephalus maladensis, among others. The faunal assemblage mentioned before is indicative of the Mexicella mexicana Zone, Albertella highlandensis Subzone, just as in the El Gavilán Formation, in San José de Gracia. Based on the aforementioned observations, and considering the abundance of agnostid trilobites, the environment deposit of these rocks is considered an open shelf (intermediate).

\section{Acknowledgments}

The authors wish to thank Dr. Silvia Martínez Retama, Head of the Department of Geology at the Universidad de Sonora, and Dr. Elena Centeno García, Director of the Institute of Geology, UNAM, for their support in conducting this research. Francisco Cuen acknowledges the Posgrado en Biocencias (DICTUS-UNISON) for providing the facilities to carry out this research and the financial and technical support of CONACYT. We greatly appreciate the financial support provided by CONACYT grants No. 165826, 235970 and EGOS Francia-México No. 229494. We express our sincere thanks to Dr. Sara Alicia Quiroz Barroso (UNAM) and Dr. Matilde S. Beresi (CONICET-CGT) for the revision of this manuscript.

\section{References}

Almazán-Vázquez, E., 2002, El Cámbrico Temprano y Medio de San José de Gracia, Sonora Central, México (resumen), in Unión Geofísica Mexicana, 22, núm. 2, 333.

Álvarez, M., 1949, Notas sobre el Paleozoico mexicano: Boletín de la Asociación Mexicana de Geólogos petroleros, 1, 47-56.

Babcock, L.E., Robison, R.A., 1988, Taxonomy and paleobiology of some Middle Cambrian Scenella (Cnidaria) and hyolithids (Mollusca) from western North America: University of Kansas Paleontological Contributions, 121, 1-22.

Bartolini, C., Morales-Montaño, M., Damon, M., 2001, Estratigrafía del Terciario y Geocronología (K - Ar) del área sur de San José de Gracia, Sonora central, México: Geological Society of America, 24, 6. Beraldi-Campesi, H., Buitrón, S.B., Guen, R.F., Montijo, G.A., 2013, Oncolitos del Cámbrico inferior de la región de San José de Gracia, Sonora (resumen), en VIII Congreso Latinoamericano de 
Paleontología - XIII Congreso Mexicano de Paleontología, 37.

Buitrón, B.E., 1992, Las rocas sedimentarias del Paleozoico inferior de México y su contenido biótico, in Gutiérrez Marco, J.G., Saavedra, J., y Rábano, I. (eds.), Paleozoico inferior de Ibero-América: Universidad de Extremadura, 193-201.

Buitrón. B.E., Almazán, V.E., Mendoza, M.G., 2004, Gogia spiralis el eocrinoide de mayor antigüedad (Cámbrico temprano) de México (resumen), in Unión Geofísica Mexicana, 24, 2, 251.

Buitrón, B.E., Vachard, D., Clausen S., Gómez, E.C., 2011, Moluscos del Cámbrico (Hyolithida, Syssoiev, 1957) de San José de Gracia, Sonora, Noroeste de México (resumen), in Félix Pico, E.F., Bertsch, H., Campay, R.C. (eds.), Reunión Internacional de Malacología, 2011, 175.

Cirett, G.J., Aguilar, R.F., 1989, Características geológicas e hidrogeoquímicas del Valle de Ures, Sonora, México: Sonora, México, Universidad de Sonora, Tesis de licenciatura, $137 \mathrm{p}$.

Cooper, G.A., Arellano, A.R.V., 1946,

Stratigraphy near Caborca, northwest Sonora, Mexico: Bulletin American Association Petroleum Geologists, 30, 606611.

Cooper, G.A., Arellano, A.R.V., Johnson, J.H., Okulitch, V.J., Stoyanow, A., Lochman, C., 1952, Cambrian Stratigraphy and Paleontology near Caborca, northwestern Sonora, México: Smithsonian Miscellaneous Collections, 119, 1-184. Cooper, G.A., Arellano, A.R.V., Johnson, J.H., Okulitch, V.J., Stoyanow, A., Lochman, G., 1956, Geología y Paleontología de la región de Caborca, norponiente de Sonora: Pt. $1^{\text {a }}$, Universidad Nacional Autónoma de México, 259.

Cuen, R.F., 2012, Sobre la Estratigrafia y

Paleontología del Cámbrico del área de San José de Gracia, Sonora central: Sonora,
México, Universidad de Sonora, Tesis de licenciatura, $73 \mathrm{p}$.

Guen, R.F., Almazán-Vázquez, E., Montijo, G.A., Minjárez, S.I., Grijalva, N.F., Monreal, S.R., Schwennicke, T., Ochoa, G., 2009, Faunas marinas de invertebrados del Cámbrico temprano y medio en la parte central del estado de Sonora, México (resumen), in Unión Geofísica Mexicana, 29, 1, 91.

Cuen, R.F., Montijo, G.A., Minjárez, S.I., De la O, V. M., Buitrón, S.B., Sundberg, F., 2012, La biota del Cámbrico de San José de Gracia, Sonora: Consideraciones bioestratigráficas, sistemáticas y paleogeográficas (resumen), in Universidad de Sonora, Departamento de Geología. XXXV Semana Cultural, 33.

Cuen, R.F., Beresi, M.S., Montijo, A., Buitrón, B.E., Minjárez, I., De la O, M., Palafox, J.J., 2013, Chancelloriia Walcott, 1920 y Reticulosa Reid, 1958 del Cámbrico medio de San José de Gracia, Sonora, México: Boletín de la Sociedad Geológica Mexicana, 65, 581-590.

Folk, R.L., 1965, Petrology of sedimentary rocks: Hemphill Publishing Company. Austin, Texas, 183.

Haldeman, S.S., 1840, Supplement to number one of a "Monograph of the Limnidae, or freshwater univalve shells of North America," containing descriptions of apparently new animals in different classes, and the names and characters of the subgenera in Paludina and Anculosa: Philadelphia, Privately printed, 3.

Huerta-Ruiz, A., 201 1, Moluscos del Cámbrico (Hyolithida, Syssoiv, 1957) de San José de Gracia, Sonora. Consideraciones bioestratigráficas, Paleoecológicas y Paleogeográficas: México, D.F., Universidad Nacional Autónoma de México Tesis de licenciatura, $53 \mathrm{p}$.

Lochman, G., 1948, New Cambrian trilobite genera from northwest Sonora, Mexico: 
Journal of Paleontology, 22, 451-464.

Maytorena-Silva, J.F., Esparza-Yañez, F.A.,

1990, The Cambrian succession of central

Sonora: Tectonic implications (abstract), in

Geological Society of America Abstracts

with Programs, 22 (3), 65.

Nardin, E., Almazán-Vázquez, E., Buitrón-

Sánchez, B.E., 2009, First report of Gogia

(Eocrinoidea - Echinodermata) from

the Early - Middle Cambrian of Sonora

(México), with biostratigraphical and

palaeoecological comments: Geobios, 42 , 233-242.

Palmer, A.R., Halley, R.B., 1979, Physical stratigraphy and trilobite biostratigraphy of the Carrara Formation (Lower and Middle Cambrian) in the southern Great Basin:

U.S. Geological Survey Professional Paper, 1047, 172.

Robison, R.A., 1965, Middle Cambrian Eocrinoids from Western North America: Journal of Paleontology, 39, 355-364.

Rivera-Carranco, E., 1988, Condiciones paleoambientales de depósito de las formaciones cámbricas del área de Caborca, Sonora: Universidad Nacional Autónoma de México, Revista del Instituto de Geología, 07, 22-27.

Seilacher, A., 1964, Biogenic Sedimentary Structures, in Imbrie, J., Newell, N. (eds.), Approaches to Paleoecology: Wiley, New York, 296-316.
Stewart, J.H., McMenamin, M.A., MoralesRamírez, J.M., 1984, Upper Proterozoic and Cambrian Rocks in the Caborca Region, Sonora, Mexico - Physical Stratigraphy, Biostratigraphy, Paleocurrent Studies, and Regional Relations: U.S. Geological Survey Professional Paper, 1309, 36.

Stewart, J.H., Amaya-Martinez, R., Palmer, A.R., 2002, Neoproterozoic and Cambrian strata of Sonora, México. Rodinian Super continent to Laurentian Cordilleran Margin: Geological Society of America Special Paper, 36, 9-15.

Sundberg, F.A., 2011, Delamaran biostratigraphy and Lithostratigraphy of the southern Nevada, in Hollingsworth, J.S., Sundberg F.A., Foster, J.R. (eds.), Museum of Northern Arizona, Bulletin, 67, 174-185.

Sundberg, F.A., McCollum, L.B., 2003, Early and Mid Cambrian trilobites from the outershelf deposits of Nevada and California, USA: Palaeontology, 46, 945-986.

Walcott, G.D., 1920, Cambrian geology and Paleontology IV: 06, Middle Cambrian Spongiae: Smithsonian Miscellaneous Collections, 67, 261-364.

Wilson, J.L. 1975, Carbonate facies in geologic history: Springer, 471. 